\title{
SATISFACTION RECEIVED TOWARDS AGRICULTURAL INFORMATION FROM TELEVISION PROGRAMS AMONG FARMERS
}

\author{
${ }^{1}$ Nor Sabila Ramli, ${ }^{2}$ Md. Salleh Hassan, \\ ${ }^{1}$ Bahaman Abu Samah, ${ }^{2}$ Muhamad Sham Shahkat Ali, \\ ${ }^{2}$ Zoheir Sabagpour Azaharian and ${ }^{1}$ Hayrol Azril Mohamed Shaffril \\ ${ }^{1}$ Laboratory of Sustainable Development and Agriculture Extension, \\ Institute for Social Science Studies, University Putra Malaysia, Malaysia \\ ${ }^{2}$ Department of Communication, \\ Faculty of Modern Language and Communication, University Putra Malaysia, Malaysia
}

Received 2011-12-14, Revised 2013-05-28; Accepted 2013-06-21

\begin{abstract}
Television is one of the top mass media to broadcast the information. It is heartening to know that mass media is playing its role in developing and strengthening the agriculture sector in Malaysia. Results from many international studies found that farmer received a high level of satisfaction from agriculture programs aired on television. However, can the similar results found among farmers in Malaysia? Therefore, this study intends to discover the Malaysian farmers satisfaction towards agricultural information aired on television. This is a quantitative study. The data collection was conducted through survey method and the respondents selected were from the states of western Malaysia Kedah and Selangor. Interestingly, both states; Kedah and Selangor recorded a similar level of satisfaction towards agriculture programs. Further analyses run have concluded that farmers in both states have a higher level of satisfaction towards information related to crops/livestock/farming and good agriculture practices. The findings of the study can be good sources and references for the agriculture programs producers to measure on the level of satisfaction of the agriculture programs aired by television among the farmers. Moreover, the findings demonstrated can help our agricultural programs producer to improve their contents in order to fulfill needs of their audience.
\end{abstract}

Keywords: Satisfaction, Agriculture Community, Agriculture Development, Television

\section{INTRODUCTION}

The first mass media in Malaysia was the newspaper, produced back in 1806 in Penang, followed later by publication of magazine in 1817. Malaysia then had taken a further step by introducing radio broadcasting in 1930 and television broadcasting in 1963. To be in line with other developing countries, Malaysian government had taken a wise step in bringing the internet technology to the country in 1987 (Ujang, 2000; Samah et al., 2011; Shaffril et al., 2010). The mass media is persistently developing and this can be proven through the establishment of quite a number of companies that own big number of mass media channels either online, electronic or printed. Media Prima for example owned several established television and radio stations such as TV3, NTV7, TV9, TV8 Al-Hijrah, Hot FM and Fly FM while ASTRO own television and radio channels such as Astro Prima, Astro Ceria, Astro Arena, Astro Awani, Era FM, Sinar FM and Hitz FM. Albeit the great contributions of the private companies towards the mass media development in Malaysia, the government

Corresponding Author: Md. Salleh Hassan, Department of Communication, Faculty of Modern Language and Communication, University Putra Malaysia, Malaysia 
on such development cannot be argued. Established television channels such as TV1 and TV2 and radio channels such as Radio Muzik and KLFM are among the mass media channels that are owned by the government and has become among the main choices of the Malaysian viewers and listeners. The power of mass media in the information dissemination process has been proven in a number of studies. Purushothaman et al. (2003) found that the success of agricultural development program in developing countries is largely depends on the nature and extent of use of mass media in mobilizating the people for development whereas in a local study conducted by Musa (2008) has shown the success of the mass media in disseminating the information when he identified that in 2007 the percentage of television information received by the public was about $93.4 \%$, followed by radio $(79.4 \%)$, daily newspaper $(55.1 \%)$, magazine $(31.7 \%)$ and internet $(17.6 \%)$.

\subsection{History of Television in Malaysia}

In its early day, television in Malaysia has generated a considerable impact to the society especially in exposing them to the taste of modernization (Karthigesu, 1994). Back in 1963, the year when television was first brought to the country, it was only aired in black-and-white. Parallel with its importance in disseminating information to the public, the operating centers for television services by that time was moved in to a well-developed premise known as Angkasapuri; which is still in used nowadays. Six years after its establishment, another history was created in 1969 when television services were aired in color. Government television services are operated under Radio Television Malaysia, an agency under Ministry of Information, Communication and Culture.

Apart from this, TV3 is the first private television channel in Malaysia. Operated under one of the leading media companies in Malaysia; Media Prima. TV3 was established in 1984 and since that Media Prima has never stopped to spread their wings in this industry, Consequently after the establishment of TV3, Media Prima has bought three others television channels namely ntv7, 8TV and TV9. ASTRO is another symbol of television development in Malaysia, it is the first paid satellite television channel in Malaysia. It is a giant media company that was established back in 1996 that own hundreds of television channels.

In Malaysia, there are five free to air television channels namely RTM1, RTM2, RTM3, ntv7, 8TV and TV9. RTM1 is the one of the stations that has persistently supported the agriculture by broadcasting agriculture programs in this country. Currently, RTM1 is airing a total of six agricultural programs for their audience.
Table 1. Schedule of agricultural programs at RTM 1

\begin{tabular}{lll}
\hline Day & Time & Program \\
\hline Sunday & $12.30 \mathrm{pm}$ & Flower*Bunga \\
& $6.00 \mathrm{pm}$ & Agro Journal *Agrojurnal \\
Thursday & $11.30 \mathrm{pm}$ & Agro Asian*Agro Asia \\
Friday & $12.45 \mathrm{pm}$ & Our Earth*Bumi Kita \\
Saturday & $12.30 \mathrm{pm}$ & Slice of Herbs*Racik-Racik Herba \\
& $6.00 \mathrm{pm}$ & Agro Tech*Agrotek \\
& $7.02 \mathrm{pm}$ & Our Earth*Bumi Kita \\
\hline Update source: 22 October 2011 *: The name of programs in \\
Malay Source: Radio Malaysia Television (RTM), 2010 \\
\multicolumn{3}{c}{ 1.2. Current Agricultural Television Programs in } \\
Malaysia
\end{tabular}

As we can see in Table 1, there are a number of agriculture television programs, among which are.

\subsection{Agro Tech}

One of the favorite's agricultural programs among agricultural community is Agro Tech which is in magazine form. It is divided into three segments which are introduction, research and development $(R \& D)$ and also discussion on new technology in agriculture.

\subsection{Agro Journal}

The documentary program focuses on agricultural activities in Malaysia. One of the objectives of this program is to fulfill the obligation in attracting the public to be interested to join this industry in Malaysia for the future.

\subsection{Our Earth}

The contents of this program are a summarized program either from Agro Tech and Agro journal programs.

\subsection{Agro Asian}

This program demonstrates agricultural issues in Asian countries such as Korea, Taiwan and China due to the advanced agricultural technology practices by farmers in these respective countries. It is expectantly that technology demonstrated to the viewers in these programs can be good examples to the local farmers. Previously Agro Asian is known as Agro Asean, a program that practiced a similar concept with Agro Asian.

\subsection{Flower}

This is another filler program produced by RTM. This program focuses on the variety of flowers in Malaysia. It is aired for $25 \mathrm{~min}$ for asegment and it is produced due to the increasing interest demand, market and potentials of the local flowers. 
Table 2. Table of demographic profile

\begin{tabular}{|c|c|c|c|c|}
\hline Demographic & Frequency & Percentage & Mean & S.D \\
\hline \multicolumn{5}{|l|}{ State } \\
\hline Kedah (Northen) & 100 & 50.0 & & \\
\hline Selangor (Central) & 100 & 50.0 & & \\
\hline Total & 200 & 100.0 & & \\
\hline \multicolumn{5}{|l|}{ Gender } \\
\hline \multicolumn{5}{|l|}{ Male } \\
\hline Female & 188 & 94.0 & & \\
\hline \multirow[t]{2}{*}{ Total } & 12 & 6.0 & & \\
\hline & 200 & 100.0 & & \\
\hline Age_categories & & & 50.53 & 0.05319 \\
\hline 1 (<20 years $)$ & 4 & 2.0 & & \\
\hline 2 (21-40 years) & 39 & 19.5 & & \\
\hline 3 (41-60 years) & 102 & 51.0 & & \\
\hline 4 (61-80 years) & 54 & 27.0 & & \\
\hline 5 (>81 years) & 1 & 0.5 & & \\
\hline Total & 200 & 100.0 & & \\
\hline \multicolumn{5}{|l|}{ Marital } \\
\hline Single & 15 & 7.5 & & \\
\hline Married & 185 & 92.5 & & \\
\hline Total & 200 & 100.0 & & \\
\hline \multicolumn{5}{|l|}{ Children_categories } \\
\hline $1(<5$ person $)$ & 148 & 74.0 & & \\
\hline 2 (6-10 person) & 49 & 24.5 & & \\
\hline 3 (>11 person) & 3 & 1.5 & & \\
\hline Total & 200 & 100.0 & & \\
\hline \multicolumn{5}{|l|}{ Education } \\
\hline Non-formal educational & 3 & 1.5 & & \\
\hline Primary school & 67 & 33.5 & & \\
\hline Secondary school/PMR & 52 & 26.0 & & \\
\hline SPM/SPMV & 66 & 33.0 & & \\
\hline STPM/Matriculation & 8 & 4.0 & & \\
\hline Diploma & 2 & 1.0 & & \\
\hline Bachelor/Master/PhD & 2 & 1.0 & & \\
\hline Total & 200 & 100.0 & & \\
\hline Experience_categories & 49 & 24.5 & 24.29 & 0.09652 \\
\hline $1(<10$ years $)$ & 51 & 25.5 & & \\
\hline 2 (11-20 years) & 41 & 20.5 & & \\
\hline 3 (21-30 years) & 31 & 15.5 & & \\
\hline 4 (31-40 years) & 28 & 14.0 & & \\
\hline 5 (>41 years) & 200 & 100.0 & & \\
\hline \multicolumn{5}{|l|}{ Total } \\
\hline Income_categories & 136 & 68.0 & 1432.6 & 0.06007 \\
\hline $1(<\mathrm{RM} 1000)$ & 48 & 24.0 & & \\
\hline 2 (RM 1001-RM2000) & 11 & 5.5 & & \\
\hline 3 (RM 2001-RM3000) & 2 & 1.0 & & \\
\hline 4 (RM 3001- RM4000) & 0 & 0.0 & & \\
\hline 5 (RM 4001-RM5000) & 3 & 1.5 & & \\
\hline $6(>\mathrm{RM} 5001)$ & 200 & 100.0 & & \\
\hline Total & & & & \\
\hline
\end{tabular}

\subsection{Slice of Herbs}

This is a new program from RTM1 which focuses on herbs in Malaysia. It is produced in 13 episodes and starts its airtime on 1st October 2011. This program is handled by a chosen celebrity and a chef. The main purpose of this program is to share and disseminate information to the audience on the variety of herbs which can be used in their cooking and for their health.

\section{MATERIALS AND METHODS}

This research employed a quantitative method. Survey was used for this research. The questionnaire was distributed to 100 farmers for each state which are Kedah (northern) and Selangor (Central). To ease the data collection process, assistance from trained and experienced enumerators was mobilized. Furthermore, assistance from the agriculture officers, village leaders and farm leaders were gained. The enumerators took an average of $20-30 \mathrm{~min}$ to complete the questionnaire. SPSS was performed to run relevant and suitable analyses (Table 2).

\section{RESULTS}

A total of 200 respondents were selected to fill up the questionnaire. Majority of respondents are male $(94 \%)$ while $6 \%$ of the respondents are female. More than half of the respondents $(51.0 \%)$ were included in the age categories of 41-60 years old while minority of the respondents $(2.0 \%)$ were included in the age of $<20$ years. This result for this study agree the majority farmers in Malaysia is still more than 40 years and above. Many of them were possess primary school level of education $(33.5 \%)$. Meanwhile, we can conclude that not too many of the respondents surveyed, have a higher level of education based on the fact that only $1.0 \%$ of them possess Diploma certificate and another $1.0 \%$ possess Bachelor/Master/PhD certificates. Furthermore, slightly more than a quarter of the respondents $(25.5 \%)$ were identified to have 11-20 years of experience in agricultural sector. Additionally, majority of the respondents $(68 \%)$ earned a total income which below than RM1000 per month. A large majority of the respondents are married $(92.5 \%)$ and near three quarter of the respondents $(74.0 \%)$ have $<5$ children.

The overall mean score $(\mathrm{M}=3.05)$ depicted in Table 3 indicates that most of the agricultural community still moderately satisfied toward agricultural programs aired on television. Table $\mathbf{3}$ shows the mean score for each statement used to measure respondents satisfaction towards agricultural information's received from television programs. 
Table 3. Perceived gratification obtained from TV programs $(n=198)$

\begin{tabular}{|c|c|c|c|c|c|c|}
\hline Statements & $\begin{array}{l}\text { SD } \\
\text { n }(\%)\end{array}$ & $\begin{array}{l}\mathrm{D} \\
\mathrm{n}(\%)\end{array}$ & $\begin{array}{l}\text { SWA } \\
\text { n (\%) }\end{array}$ & $\begin{array}{l}\mathrm{A} \\
\mathrm{n}(\%)\end{array}$ & $\begin{array}{l}\text { SD } \\
\mathrm{n}(\%)\end{array}$ & Mean \\
\hline Good agricultural practices for Crops/Livestock & $\begin{array}{l}4 \\
(2.0)\end{array}$ & $\begin{array}{l}4 \\
(2.0)\end{array}$ & $\begin{array}{l}42 \\
(21.2)\end{array}$ & $\begin{array}{l}98 \\
(49.5)\end{array}$ & $\begin{array}{l}50 \\
(25.3)\end{array}$ & 3.9394 \\
\hline Latest updates for farmers on Crops/Livestock/Farming. & $\begin{array}{l}5 \\
(2.5)\end{array}$ & $\begin{array}{l}2 \\
(1.0)\end{array}$ & $\begin{array}{l}47 \\
(23.5)\end{array}$ & $\begin{array}{l}91 \\
(45.5)\end{array}$ & $\begin{array}{l}53 \\
(26.5)\end{array}$ & 3.9343 \\
\hline To help farmers solve problems related to production of Crops/ Livestock & $\begin{array}{l}6 \\
(3.0)\end{array}$ & $\begin{array}{l}13 \\
(6.5)\end{array}$ & $\begin{array}{l}54 \\
(27.0)\end{array}$ & $\begin{array}{l}112 \\
(56.0)\end{array}$ & $\begin{array}{l}13 \\
(6.5)\end{array}$ & 3.7424 \\
\hline $\begin{array}{l}\text { To improve farmers skills and knowledge about } \\
\text { controlling the diseases of Crops/Livestock }\end{array}$ & $\begin{array}{l}8 \\
(4.0)\end{array}$ & $\begin{array}{l}8 \\
(4.0)\end{array}$ & $\begin{array}{l}41 \\
(20.5)\end{array}$ & $\begin{array}{l}112 \\
(56.0)\end{array}$ & $\begin{array}{l}29 \\
(14.5)\end{array}$ & 3.7374 \\
\hline To provide farmers with knowledge regarding pest control & $\begin{array}{l}9 \\
(4.5)\end{array}$ & $\begin{array}{l}7 \\
(3.5)\end{array}$ & $\begin{array}{l}44 \\
(22.0)\end{array}$ & $\begin{array}{l}105 \\
(52.5)\end{array}$ & $\begin{array}{l}33 \\
(16.5)\end{array}$ & 3.7374 \\
\hline Help farmers to find market for their products & $\begin{array}{l}4 \\
(2.0)\end{array}$ & 7 & $\begin{array}{l}57 \\
(28.5)\end{array}$ & $\begin{array}{l}98 \\
(49.0)\end{array}$ & $\begin{array}{l}32 \\
(16.0)\end{array}$ & 3.5707 \\
\hline Farming loans and credits provided by organizations & $\begin{array}{l}42 \\
(21.0)\end{array}$ & $\begin{array}{l}31 \\
(15.5)\end{array}$ & $\begin{array}{l}49 \\
(24.5)\end{array}$ & $\begin{array}{l}58 \\
(29.0)\end{array}$ & $\begin{array}{l}18 \\
(9.0)\end{array}$ & 2.8939 \\
\hline To keep farmers up-to-date on reliable weather and climate information & $\begin{array}{l}48 \\
(24.0)\end{array}$ & $\begin{array}{l}40 \\
(20.0)\end{array}$ & $\begin{array}{l}47 \\
(23.5)\end{array}$ & $\begin{array}{l}40 \\
(20.0)\end{array}$ & $\begin{array}{l}23 \\
(11.5)\end{array}$ & 2.7475 \\
\hline To assist farmers as a source of price information & $\begin{array}{l}54 \\
(27.0)\end{array}$ & $\begin{array}{l}30 \\
(15.0)\end{array}$ & $\begin{array}{l}58 \\
(29.0)\end{array}$ & $\begin{array}{l}45 \\
(22.5)\end{array}$ & $\begin{array}{l}11 \\
(5.5)\end{array}$ & 2.6414 \\
\hline To give a complete and timely weather information to farmers & $\begin{array}{l}70 \\
(35.0)\end{array}$ & $\begin{array}{l}24 \\
(12.0)\end{array}$ & $\begin{array}{l}50 \\
(25.0)\end{array}$ & $\begin{array}{l}32 \\
(16.0)\end{array}$ & $\begin{array}{l}22 \\
(11.0)\end{array}$ & 2.5556 \\
\hline Overall mean & & & & & & 3.0500 \\
\hline
\end{tabular}

*SD = Strongly Disagree, D = Disagree, SWA = Somewhat Agree, A = Agree, SA = Strongly Agree

Table 4. Perceived gratification obtained from TV programs for each states $(n=99)$

\begin{tabular}{|c|c|c|c|c|c|c|}
\hline Statement & $\begin{array}{l}\text { SD } \\
(\%)\end{array}$ & $\begin{array}{l}\text { SD } \\
(\%)\end{array}$ & $\begin{array}{l}\text { SD } \\
(\%)\end{array}$ & $\begin{array}{l}\text { SD } \\
(\%)\end{array}$ & $\begin{array}{l}\text { SD } \\
(\%)\end{array}$ & $\begin{array}{l}\text { SD } \\
(\%)\end{array}$ \\
\hline Latest updates for farmers on Crops/Livestock/FarmingKedah & 2.5 & 1.0 & 23.5 & 45.5 & 26.5 & 4.01 \\
\hline Selangor & 5.0 & 2.0 & 25.3 & 40.4 & 27.3 & 3.83 \\
\hline \multicolumn{7}{|l|}{ Good agricultural practices for Crops/Livestock } \\
\hline Kedah & 2.0 & 2.0 & 21.0 & 49.0 & 25.0 & 3.97 \\
\hline Selangor & 3.0 & 2.0 & 27.3 & 39.4 & 28.3 & 3.88 \\
\hline \multicolumn{7}{|c|}{ To help farmers solve problems related to production of Crops/ Livestock } \\
\hline Kedah & 3.0 & 6.5 & 27.0 & 56.0 & 6.5 & 3.84 \\
\hline Selangor & 3.0 & 4.1 & 31.3 & 51.5 & 10.1 & 3.62 \\
\hline \multicolumn{7}{|l|}{$\begin{array}{l}\text { To improve farmers skills and knowledge about } \\
\text { controlling the diseases of Crops/Livestock }\end{array}$} \\
\hline Kedah & 4.0 & 4.0 & 20.5 & 56.0 & 14.5 & 3.73 \\
\hline Selangor & 4.0 & 5.1 & 22.2 & 53.5 & 15.2 & 3.71 \\
\hline \multicolumn{7}{|l|}{ To provide farmers with knowledge regarding pest control } \\
\hline Kedah & 4.5 & 3.5 & 22.0 & 52.5 & 16.5 & 3.73 \\
\hline Selangor & 4.0 & 5.1 & 24.2 & 49.5 & 17.2 & 3.71 \\
\hline \multicolumn{7}{|l|}{ Help farmers to find market for their products } \\
\hline Kedah & 2.0 & 3.5 & 28.5 & 49.0 & 16.0 & 3.57 \\
\hline Selangor & 2.0 & 4.0 & 38.4 & 47.5 & 8.1 & 3.56 \\
\hline \multicolumn{7}{|c|}{ To keep farmers up-to-date on reliable weather and climate information } \\
\hline Kedah & 24.0 & 20.0 & 23.5 & 20.0 & 11.5 & 2.88 \\
\hline Selangor & 33.3 & 15.2 & 27.3 & 10.1 & 14.1 & 2.57 \\
\hline \multicolumn{7}{|l|}{ Farming loans and credits provided by organizations } \\
\hline Kedah & 21.0 & 15.5 & 24.5 & 29.0 & 9.0 & 2.83 \\
\hline Selangor & 23.2 & 10.1 & 26.3 & 30.3 & 10.1 & 2.94 \\
\hline \multicolumn{7}{|l|}{ To give a complete and timely weather information to farmers } \\
\hline Kedah & 35.0 & 12.0 & 25.0 & 16.0 & 11.0 & 2.67 \\
\hline Selangor & 43.4 & 9.1 & 25.3 & 9.1 & 13.1 & 2.40 \\
\hline \multicolumn{7}{|l|}{ To assist farmers as a source of price information } \\
\hline Kedah & 27.0 & 15.0 & 29.0 & 22.5 & 5.5 & 2.65 \\
\hline Selangor & 2.0 & 4.0 & 38.4 & 47.5 & 8.1 & 2.62 \\
\hline
\end{tabular}

*SD = Strongly Disagree, D = Disagree, SWA = Somewhat Agree, A = Agree, SA = Strongly Agree 
Based on the result presented, respondents were identified to have a high level of satisfaction towards two types of information namely good agriculture practices for crops and farms $(\mathrm{M}=3.94)$ and updated information on crops and farms $(\mathrm{M}=3.93)$. Apart from this, the respondents demonstrated a moderate level of satisfaction towards received agriculture information related to as a solver for their problems related to crops and farms $(\mathrm{M}=3.74)$, can improve farmers skills and knowledge about disease control $(\mathrm{M}=3.74)$, also knowledge about pest control $(\mathrm{M}=3.74)$ and assisting farmers to search suitable markets for their products (M $=3.57$ ). Based on the mean score gained it can be concluded that they agree the agricultural information's received from television didn't show much information on the credit and loan provided by related agencies $(\mathrm{M}=$ $2.89)$, current weather information $(\mathrm{M}=2.75)$. list of price (2.64) and detailed and accurate weather information $(\mathrm{M}=2.56)$.

Table 4 specifically informs on the ten statements used to measure the satisfaction received from agriculture programs aired on television. The analyses have identified that percentage for each statements by states were ranging from lowest $(\mathrm{M}=2.65)$ to highest $(\mathrm{M}=4.01)$ for Kedah. The similar case was also detected for farmers in Selangor with mean score ranging from $(\mathrm{M}=2.40)$ to $(\mathrm{M}=3.88)$. Farmers in Kedah were found to have a higher satisfaction on information relevant to crops/livestock/farming $(\mathrm{M}=$ 4.01). Unlike Kedah, farmers in Selangor were identified to have highest satisfaction on information related to good agriculture practices for crops/livestock $(\mathrm{M}=3.88)$. Meanwhile, farmers in both states; Kedah $(M=35.0)$ and Selangor $(M=43.4)$ agreed that they felt less satisfaction towards information pertinent to complete and timely weather information.

\section{DISCUSSION}

Based on the result analyzed, the level of satisfaction towards agricultural television programs is not much differences for both states.

It means that probably farmers in both states have benefited equally by the agriculture information received. Most of respondents agreed that there are still inadequate numbers of agriculture information disseminated to them. Findings of this study can be good 'assistant' to the producers' of programs in term of identifying the actual information needed by the audiences. To understand what are the real needs of the farmers is the key for any television programs success (Hussain, 2008; Hassan et al., 2009; 2010a; 2010b). Eventually, by having this kind of information will enable the producers to attract more audience to follow and attach to the agriculture program. Furthermore, at the same time, the farmers can be assisted in getting new lessons to increase their skills and knowledge in agricultural sector.

\section{CONCLUSION}

For the conclusion, the program producer needs to think how to improve their contents of program to give more beneficial information to audience. It is because television plays a major role to disseminating information to all people. Therefore we need to grab this opportunity to upgrade our agricultural program in television to transform our agricultural industry to the next level.

\section{REFERENCES}

Hassan, M.S., H.A.M. Shaffril, B.A. Samah, M.S.S. Ali and N.S. Ramli, 2010a. Agriculture communication in Malaysia: The current situation. Am. J. Agric. Biol. Sci., 5: 389-396.

Hassan, M.S., H.A.M. Shaffril, B.A. Samah, M.S.S. Ali and N.S. Ramli, 2010b. Producing television agriculture program: Issues and problems among malaysian television producers. J. Soc. Sci., 6: 356-360.

Hassan, M.S., H.A.M. Shaffril, M. Abu Hassan, B. Abu Samah and M.S.S. Ali, 2009. Mass Media, ICT, Agriculture Community and Agriculture Extension: Efforts towards Developing Agriculture Extension in Malaysia in Bahaman. In: Media and Agriculture Extension: Towards Strengthening the Rural Community, Jegak, A.S.U. and A. Dan Khatijah (Eds.), UPM Publisher, Serdang, pp: 32-48.

Hussain, M.Y., 2008. Mass Media in Selected Muslim Countries. 1st Edn., International Islamic University Malaysia, Kuala Lumpur, ISBN-10: 9833855385, pp: 222.

Karthigesu, R., 1994. History of television development in Malaysia (1963-1983). Dewan Bahasa dan Pustaka, Kuala Lumpur.

Musa, A.H., 2008. Benefiting ICT for all. Inaugural Lecture Series. UPM, Serdang.

Purushothaman, C., M. Kavaskar, Y.A. Reddy and K. Kanagasabapathi, 2003. Role of mass media in agriculture. 
Samah, B.A., H.A.M. Shaffril, M.A. Hassan and J.L. Silva, 2011. Can technology acceptance model be applied on the rural setting: The case of village development and security committee in Malaysia. J. Soc. $\quad$ Sci., 7: 113-119. DOI: 10.3844/jssp.2011.113.119
Shaffril, H.A.M., B.A. Samah, M.A. Hassan and J.L. Silva, 2010. Socio-economic factors that impinge computer usage in administration works among village leaders in Malaysia. Sci. Res. Essays, 5: 3623-3633.

Ujang, Z., 2000. Internet in Malaysia: An Introduction. 